\title{
Autonomous Histories of Muslim Women Cultural Poetics; A Critical Reading of the Personal/Academic Narratives of Leila Ahmed and Amina Wadud
}

\author{
Hadeer Abo El Nagah \\ Prince Sultan University, Saudi Arabia \\ E-mail: habouelnagah@psu.edu.sa
}

Received: 07-10-2016

Accepted: 19-12-2016

Advance Access Published: January 2017

Published: 01-03-2017

doi:10.7575/aiac.ijalel.v.6n.2p.192

URL: http://dx.doi.org/10.7575/aiac.ijalel.v.6n.2p.192

\begin{abstract}
Louis Montrose's "Professing the Renaissance: the Poetics and Politics of Culture" renewed concern with the historical, social and political conditions of literary productions (1989). He suggested a platform through which autonomous aesthetics and academic issues to be understood as inextricably linked to other discourses. While autobiography is considered as a "writing back," I argue here that it is rather a strategic transitional act that connects the past with the present and remaps the future. Though a very personal opening, autobiography is seen as a documentation of public events from a personal perspective. Academic autobiographies like Arab American history professor Leila Ahmad's $A$ Border Passage from Cairo to America; A Woman's Journey (2012) and African American theology professor Amina Wadud's Inside the Gender Jihad (2008) are two examples of the production of interwoven private and public histories. The personal opening in such narratives is an autonomous act that initiates cross-disciplinary dialogues that trigger empowerment and proposes future changes. In that sense, these autobiographies are far from being mere stories of the past. Conversely, they are tools of rereading one's contributions and thus repositioning the poetics and politics of culture as testimonial narratives. Employing post-colonial, Islamic feminism and new historicism, the aim of this study is to critically read the above academic/personal two autobiographies as examples of the private/ public negotiations of culture. It also aims to explore the dialogue between the literary, historical and social elements as they remap the future of women in Muslim societies and the diaspora.
\end{abstract}

Keywords: New Historicism, Women in Islam, personal narratives, Amina Wadud, Leila Ahmed, post-colonialism, autobiography, non-white feminism

\section{Introduction}

Louis Montrose's "Professing the Renaissance: the Poetics and Politics of Culture" renewed concern with the historical, social and political conditions of literary productions (1989). He suggested a platform through which autonomous aesthetics and academic issues are to be understood as inextricably linked to other discourses and practices (Rivkin \&Ryan 2004). Current literary debates witness a much clamor for a return to historical scholarship in the academic study of literature which renders timely critical opinions to move literary readings from the "text-centered" approach (Myers 27). In that sense, the "New Historicism" as a critical approach proves its pragmatic suitability to reading particular literary texts as it connects the text with its social and political circumstances and provides the reader with a more inclusive vision. Stephen Greenblatt who founded the "New Historicism"i Who coined the term "the Poetics of Culture," he emphasized that literature is the primary focus of the movement. In his Renaissance Self- Fashioning Greenblatt considered literature as one of the social forces that contribute to the making of individuals (4). Accordingly, the critical reading of literary texts from a historical perspective may suggest change and proposes redefine movement towards the future. Likewise, writers and literary critics such as Eric Sundquist demonstrated examples of how literature works to shape perceptions of the social world and to bring about changes in social institutions (620). Other literary analytical tools can also be utilized to enable extensive critical readings of texts that incorporate multiple elements. The intersection of postcolonial and feminist reading has currently become more in use as it allows a thorough understanding of the poetics of the texts using Greenblatt term. It also, in turn, provides a clearer perception of their effect on the fashioning of the identity (7).

Feminism, in particular, according to D. G. Myers seems to have solved the problem of reading literary texts as "ethereal entities" floating above the strife of history as it holds hopes of transforming literary criticism and proposes agents for social change (28). As debates on multiculturalism are going on around the world and especially in societies with immigrants from different roots, the cultural difference has been particularly vexing to many especially to feminists who do not belong to the white euro feminist tradition. The critique raised by black feminists for instance consistently points to issues of white universalism and homogeny (Smith 1982). Black feminism, critical race feminism, postcolonial feminism and even religious feminism, as Akila Choudhry points out, are believed to have staked out epistemological authority and have started to question dominant liberal white feminism inclusion (228). Women of 
color feminists ${ }^{\mathrm{ii}}$ raise such questions in their writings like Bell Hocks', June Jordan's Some of Us Did Not Die (2002), Fawzia Afzal-Khan's Shattering the Stereo Types (2005), Audre Lorde's Sister Outsider (1984, 2007) and in Kum-Kum Bhavnani's "Race"( 2003) to name only a few. Similarly, both writers discussed here, Ahmed and Wadud highlighted that Islamic feminism is to be distinguished from mainstream white feminism (Ahmed, Border 291-3, 296 \& Wadud, Inside 55-87) ${ }^{\mathrm{iii}}$. Islam is not only the legitimate signifier to Muslim women scholarship on feminism, but it is also the base that allows them to have control over their voice and autonomy. It is the demarcation of their cultural poetics both on the personal and communal levels. As advocates of Muslim women equity both Leila Ahmed and Amina Wadud address the premise of Islamic history from which they have to operate to achieve equity within Islam as signified legitimacy (Fernea xv). In that regard, Akila Choudhry argues that for women of particular indigenous culture to have physical control over their bodies, voice, and autonomy, it has to be activated through their cultural and religious structures. Thus historical autonomy according to Choudhry, has to happen without the others' influence (242).

The practice of autobiography or self-writing is precisely novel to Arabic literature in general and Arab women writings in particular. It rapidly distinguishes itself within this male dominated arena from which women were considered "ghostly absence" for generations (Nash 351). Strategically, the emerging personal, sociopolitical Arab women openings can be seen as a backdoor approach to criticizing women's conditions through inscribing personal narratives (Vinson 78). Such real self-narratives juxtapose the original literary fantasy of Muslim women historically originated with Orientalism and increasingly resonated after 9/11. They provide an authentic insider voice to challenge the women's image created through what Joan Wallach Scott called "fantasy echo" (Yaqin 172) ${ }^{\mathrm{iv}}$. While autobiography as a literary text perspective as a "writing back" (dinner 15), I argue here that it is rather a strategic transitional act that links the past with the present and remaps the future. The autobiography as a self/communal narrative offers a critical looking back at one's own cultural heritage that allows the narrator to include the event and her perspective on it, in addition to its effect on the personal and the public lives. The scope of this paper is the cultural/gender challenges facing the independence and self-realization of Muslim women both at Arab societies and in the diaspora. Academic autobiographies as coined by Rocio Davis (2009), provide a rich account to the reader as they analyze the personal life from an academic and professional perspectives. The two autobiographies selected for analysis here are; Leila Ahmed's A Border Passage from Cairo to America $(1999,2012)$ and Amina Wadud's Inside Gender Jihad; Women's Reform in Islam (2006-8). There are some common grounds these narratives share; both are written by women academics who have their scholarly weight in the field of Muslim women studies in particular. Both writers have had already published and presented extensively in the area of Muslim women empowerment and autonomy. Thus both are widely known figures in the field ${ }^{\mathrm{v}}$. Both are of African origin who currently live and teach in America. Both memoirs appear during a significant time in Islamic history as debates about Islam in general and women in Islam, in particular, are at their heights. Though they distinctively vary in their life stories, they share the interest of creating a clearer and better understanding of Muslim women position through rethinking Islamic heritage and culture. Through their insights to their own autobiographic narratives, both writers provide examples of Muslim women struggles linked to the Islamic and cultural heritage they belong to. More importantly to this research is the critical views of both writers as they used their own lives as a corpse for a reflective, analytical account. The personal opening instigates the cross-cultural dialogue clearly intended in the two texts, as they incorporate multiple social, religious, literary and linguistic factors. The originally personal narratives are then to be considered as testimonial narratives of a very social and communal nature as explained by Gillian Whitlock 2015 and thus diverges substantially from the predominantly white male Western cannon of autobiography (2-3). As they write back their life stories, both writers implement academic knowledge and practice to recreate autonomous histories of Muslim women. Using post-colonial, feminist and new historicism tools, the objective of this study is to analytically read the two autobiographies as examples of Muslim women self-realization and repositioning within the cultural poetics and politics of their societies and in the diaspora. It also aims at exploring the literary, historical and linguistic dialogue initiated in the selected narratives. Though following different approaches, this comparative analysis suggests that both scholars are promoting Muslim women advancement through applying an analytical rereading of women position in Islamic history and culture. It also explores their efforts in carving a position of Muslim women studies within Western feminist academia.

As a historian and theologian, Leila Ahmed's work is mainly occupied with finding women's voice through analyzing their position in pre and early Islamic history. She applied history based feminist analysis to find solutions to the challenge of women in Islam, and to engage the women voice in the debate about Islam and modernity ${ }^{\mathrm{vi}}$. Anne Tuppurianen describes Ahmed's historic approach in finding strength for implementation of change by women groups as a looking back approach with the intention of the women question as she depends mostly on history and historic events in her analysis (249). Conversely Amina Wadud's Looking forward applies a more linguistic and hermeneutic approach and calls for building structures and solidarity amongst Muslim women writers vii (Tuppurianen 225). According to both Ahmed and Wadud writing one's life is an act of self- assertion to inscribe female narratives to the textual tradition of their peoples (Vinson 2008 90).

\section{Leila Ahmed: Identifying Muslim Women Voice in Personal / Professional Narratives:}

Leila Ahmed belongs to the Egyptian upper class; she witnessed the changing political and social atmosphere of the country during the revolution of 1952. She was influenced by her father's open-mindedness, fairness to women and admiration to world leaders like Gandhi. She was also influenced by his resistance to Arab nationalism and his opposition to Jamal Abdel Nasser's regime; such opposition would eventually cause the family all its possessions. Ahmed's Yugoslavian Catholic nanny whom she spent most of her childhood affected her openness and acceptance of 
others which became pivotal in the intermediary role she later played connecting Western and Middle Eastern cultures (Tuppurianen 107).

Ahmed's approach to her memoir is positively affected by Thomas Tweed's theory of religion as a matter of crossing borders (Barbour 722). She builds bridges of understanding as her "Passage" crosses the boundaries that limit the identity of herself and other Muslim women in the diaspora. She explains: "for after that my life becomes part of a story of people of color in America, the story of women in America, the story of Muslims in America and part of the story of America itself and the American lives in a world of dissolving boundaries and vanishing borders" (Border 296).

Ahmed's Islamic education as a little girl was limited to the short Quran passages taught to her by her grandmother, a condition that she shared with many upper-class girls at her time. She was also educated at language schools and preferred to use English as her language of communication with her siblings which was also common in her social circles. Her diversified upbringing and Western education allowed her to make friends with girls from different religious backgrounds. Like all her siblings, Ahmed positively in Western primary all through her life. She attended the English school in Cairo where the majority of the teachers were not Arabs. She earned her degree in history from Girton College in England and went to Cambridge for her post graduate degrees. Ahmed migrated to America in the late seventies and started her academic career at women's studies teaching part time at Amherst College and later at her current position as a full-time professor at Harvard.

Ahmed applied a historical reading of women status in Islam in her personal life as an example, she used her own life as a material for reflection and looking back to evaluate the situation of women in Egypt before and after the 1952 revolution. History is the protagonist in Ahmed's narrative (Davis 117), yet it is not the history that is written in books, it is rather the one lived by people. Historical events are accompanied with its implications on people's lives and the effects they have on their futures. Ahmed's historical/academic and personal autobiography incorporates three parallel lines of critical analysis and self-autonomy; the historical, the postcolonial and the feminist. The three are enmeshed in her reflection and her rereading life and that of the people around her. She uses the narrative of her life as a foundation for critique, as she looks back at her own life, the individual story supports the articulation of the public history (Davis 110). The dialogue between the personal, professional and the public lives in Ahmed's memoir is a technique that is used by other women academics. It can be seen as a creative combination that utilizes theoretical agency to harness possibilities $^{\text {viii }}$. The quality of remembering is an act of openness to the past and reviewing one's position through different lenses. Ahmed's approach incorporates the literary, exemplified in her descriptive developing selfconsciousness technique and the historic events in Egypt and the world. She writes back the events along with her reading and reflections: "Once I had arrived at this point I began to be able to reflect on, and for the first time to see, events, in the past with clarity and to even remember things that I had forgotten" (Border, 26).

The three focal stations in Ahmed's personal narrative are namely Cairo, Europe, and America figuratively highlights her passage of identity finding. It also demonstrates her journey of redefining her voice. The voice of Ahmed's narrative suggests personal and professional redefinition; she looks back at her own journey from a Western academic perspective as she reconstructs her identity as an Arab and a Muslim within the terminology that was still under definition when she was growing up. She emphasized "my childhood fell in that era when the words "imperialism" and the "West" had not yet become synonyms for "racism and "oppression" and "exploitation" (Border 5). Several selfredefinitions occur through her looking back at her personal narrative; the first as she, along with fellow Egyptians, had to redefine themselves within the Arab Nationalism during the Nasr period of the 1950s after the Egyptian revolution. The second is her self-redefinition as a Muslim woman, and the third is her scholarly self-realization as a specialist in women studies as an adult living and working in the diaspora. The three lines of self-realization are concurrent and inseparable both in her life narrative and in this multiple reading as well. The following analysis of Ahmed's reflection of her own entirely is not intended to be chronological nor comprehensive. It rather examines some of the turning points in her personal and academic life and their direct or indirect effect on her personal autonomy and the empowerment of Muslim women in general.

Ahmed creates a critical connection between her academic writings about Muslim women and her own account growing up as one. She narrates both her personal and professional young adulthood within the context of social and political changes in Egypt. The title suggests the distance she traversed from her original home in Cairo to her current status as a professor at Harvard. It also summarizes the cultural journey she undertook, and her consciousness of the selfexploration and redefinition she went through (Nash 353). Adding her story to the public cultural record, she became part of that record, and her reflection of her own life becomes part of her professional analysis of Muslim women's history, as Rocio, G Davis puts it "it is history in itself" as rethought, articulated and revised (117). In that regard, Ahmed's Border is compared to and considered as a continuation to Huda Sharawi's memoir Harem Years: The Memoir of an Egyptian Feminist 1940. Sharawi's memoir is regarded as a historic and political pamphlet and probably the first women documentation of private life. She mixed the personal and the communal history (an individual 35) (ix $^{\text {. }}$

Ahmed's memoir picks up where Sharawi's had ended; from the "Harem" as her point of departure witnessing the dawn of the Harem days in her grandmother's circles at a young age which she suggested in the title of chapter headings of her narrative (Nash 354). Despite the fact that the "Harem" theme is a concurrent theme in the writings about Arab and Muslim women, Ahmed's usage of the Harem is rather authentic and not in any way to be seen as a recycling of the Western "fantasy echo" described above (Yaqin 172). Conversely, she utilized it to refer to an end of an era and a beginning of a new one. She emphasized that her primary motive to write her memoir is to respond to Western misconception against Muslim women: 
Living now in America I found myself postgraduate encountering people who made assumptions, and usually quite wrong assumptions about Islam or about what it was like to grow up a Muslim girl and what that society was like and so on. Besides saying "no that wasn't how it was," and making some general reply, I had no simple way of conveying what that world had in fact been like. And so in part this book was written out of the need to be able to say here, this what it was like to grow up a Muslim girl, read this (Ahmed Border 1).

Ahmed uses the Harem which symbolizes Muslim women oppression in Western writings as an example of the colonial promotion image about the "fetishized" East (Said 1978 72). She compared Girton College in England to the Harem tradition in the Turco pre-revolution Egypt in a chapter titled "The Harem Perfected" in her memoir. The comparison is far from being descriptive it is rather a critical reading of the Western Harem tradition. "Girton, that is to say was a version of the community of women- the harem- as I had lived it every summer in Alexandria" (Ahmed Border 181). She sees Girton as the "Harem perfected" not that of the Western idea of the male dominance and oppressive female community but the harem that represents female independence, elderly supervision, hierarchy, respect for traditions and most importantly the permanent absence of male authority (Border,183). Girton resembles the positively not only in its being a gender segregated community but also in its class division and strict traditions. Ahmed's perception of the harem was certainly not fully negative as she expressed that she is "privileged" to have lived both harem traditions, the Turco- Egyptian and the British one, she also witnessed the ending of both as male professors were allowed to Girton during her post-graduate years (Border 183).

Ahmed felt completely at home at Girton for the whole environment, and landscape reminds her of her upbringing in its landscape, hierarchy, and traditions. The analogy directed her attention to the double standard of the Western liberal views and criticism of the Third World culture and its attacked backwardness of the oppressive social class system (Border 183). from She critically addressed the "guilt-free" system that legitimizes the exploitation of others by coating the realities of things with "democratic" invented names. She also criticizes the white Western feminism for its toleration and justification of poor women exploitation as long as it supports the pursuit of "higher things" (Ahmed Border 182).

Though not a fully supporter of the master/servant relation that was common in the social setting she grows up into; Ahmed finds it more humane and compassionate than the professionalized dry $\operatorname{gyp}^{\mathrm{x}} /$ teacher and helper legalized at Girton symbolizing colonial double standards. Despite being relations of power, her grandmother's to her maid Umm Said and her mother's to Fathia are certainly more intimate than those she saw between the faculty at Girton and the perspective or helper. She sees Umm Said's sitting on the ground calmly massaging her grandma's legs during women gathering at Zatoun, her grandma's house. and their maid Fathia asking for a photo of her mom's to hang on her wall as a reminder of her after her death as examples of the intimacy that Girton's relations lack (Border 103, 183)

Ahmed's Girton experience was also an eye opener to the discrimination of the Western feminism and its fake plurality and inclusiveness. Such experience changed her prospective in reading Euro- white feminists' views of Muslim and Arab women in general and their discriminative categorization of the harem women as "inferior," "ignorant," "mindless" and "worthless" as described by Harriet Martineau for instance. Though Ahmed herself does not see the worth or significance of the discussions she heard in her family's women community or harem, she rejects discriminative comments like those Martineau wrote after visiting Egypt. Especially that she speaks no Arabic and thus shouldn't be, according to Ahmed, judgmental and biased to all Muslim women (Border 193). Ahmed's analysis of the intersection between the colonial and the feminist reading of women belonging to certain cultures and describing them as "backward" is also addressed by Akila Choudhry. Choudhry emphasized that the relation between "backward cultures" and colonialism has to be entangled and unpacked to lift the burden on women's shoulder (240).

Ahmed's sense of self-realization growing up in the segregated community of the harem, she acknowledges that she wanted to differ from that prototype as they represent everything she does not want to be. Unconsciously she identified herself with the Western women she read about in books and watched in movies (Border 193). Yet when she moved to America during the early seventies and joined the field of women studies, she realized that White/Western feminism inadequately represent Muslim women's struggle for equity as it looks at their struggle form a selective discriminative viewpoint. Like other feminists of color in the West, Ahmed realized that racism is thus an additional perspective through which Muslim women issues are to be discussed through (Border 291). She was shocked with the barrage, hostility and ignorance she found in the community of women studies along with the hatred against Islam in general. Though women studies was still then a relatively new field, Ahmed emphasized that she deliberately chose to join it despite all the hardships she encountered to rethink the Islamic heritage from a women's perspective (Border 292-3), though she could have just dismissed her Islamic identity as most Muslim academics do (Barbour 721).

After returning to Cairo for few years and going back to Cambridge for a post graduate study fellowship, Ahmed's identity as an Arab was challenged while, at the same time, she affirmed her Egyptian and Islamic self (Barbour 719). It was then when she was inspired to write her memoir as she attempted to define herself (Ahmed Border 253). Her return to England at the late sixties was at a time were the ideas of Frantz Fanon of imperialism were at its peak. Along with figures like Fanon, she studied Paolo Friere, Alberto Memmi, and Edward Said. The emerging intellectual thought of imperialism and post-colonialism allowed her to look back at her life and "interrogate, reinterpret and re-evaluate the lives and work of the generations that preceded us....... to see what they apparently had not seen, the psychological consequences of colonialism and the silent, insidious process of internalized colonialism" (ibid 33-4). 
Cambridge dawned the second stage of Ahmed's life and the development of self- definition within the scholarly free thinking setting that wasn't available in Egypt. However at Cambridge Ahmed felt lonely and confused as she first hand experienced the dismissive and pejorative attitudes towards Arabs that Edward Said would later analyze in Orientalism (Barbour 717). Along with other students from the Third World or the colonized world, Ahmed experienced what she called "the problem with no name," using Betty Friedan's words as she explains "We too were living in a society that insidiously and pervasively undermined our own experience, our own perspective" (Border 226). Said's work helped Ahmed and other scholars to be engaged in analyzing Orientalism as it gave them the language of which to speak. She describes the book along with Said's other works as "transformative" as they transformed the intellectual landscape and defined their self- realization which was earlier quite undefinable ( ibid 242). The intersection of post-colonial and feminist analysis allowed Ahmed to reexamine the development of women in Islamic history, she explained in her Women and Gender in Islam that atonement of native culture was posed as the solution for women's oppression only in colonized or dominated societies and not in the Western ones (1992 129-68).

Ahmed's journey of self- realization and rethinking of autonomous history is a journey across borders as her title suggests. It is a journey with intention of creating connections between the different cultures she belongs to. Her story becomes part of other stories as she points out:

It became part of the story of feminism in America, the story of women in America, the story of people of color in America, the story of Muslims in America, and part of the story of America itself and of American lives in a world of dissolving boundaries and vanishing borders (Ahmed Border 296).

To enhance the theme and purpose of crossing, Ahmed uses a collage of techniques in rewriting her personal history and providing an example of the history of women in Muslim societies both at home and in the diaspora. She blends in quotes from Arabic and English literature in addition to the critical readings she provides which distanced her memoir from being a simple account of history ; it frequently quotes Rumi in reference to the universality of spirituality and internationalization of humanity. She quotes other Arab and Western poets as well; Ahmed uses the tension between the spoken and the unspoken words and she records her observations of the birds and other musical sounds in nature around her. She uses slang and listens to the sound of silence around her which affected her reflections and left certain impression of places that she perspective. As she opens her memoir with the sound of music of birds and trees movements in her family's garden in Cairo, she closes the memoir with a Rumi's quote questioning "I wonder why I ever thought/ to use the language" (Ahmed Border, 306).

Ahmed's autobiography thematizes the issue of the cultural difference between Islamic practices in the Middle East and the Western ideas about women in Islam (Hassan 90). With the particular focus on women's history, Ahmed is providing an example of how the Muslim woman is not typically portrayed in the Western writings in general. She demonstrated the autonomous quality of women history as she links problems with the present moment in her second edition of her memoir. The Afterword added in the 2012 publication includes her comments and critical reading of the current situation of Islam in America as she observes how it is developing in the country especially after 9/11(311). As an academic and a writer Ahmed became more engaged in the charged and fierce debate about Islam and Muslim women in America. The changing histories of the countries of the Middle East especially after Egypt's $25^{\text {th }}$ of January Revolution 2011 have positively affected the debate. Ahmed commented on the autonomous position of the Egyptian women activists and their role in changing the country. In the afterward, she wrote about the young Egyptian woman activist Asmaa Mahfouz and compared her to Rosa Parks and Martin Luther King Jr. in their resistance to tyrannical regimes and discriminative situations. In a globalized world, Ahmed commended figures like Mahfouz who was visiting America after the revolution as she may energize American movements and inspire change (Border 317).

Though described as a looking back approach, Ahmed's approach in reading her life is not in any way to be considered as a call for backwardness. It is rather an approach to Muslim women's advancement through a rereading of personal and public history. It is her methodology in rethinking history for the purpose of the promotion of women position within the Islamic context. Such technique lends itself to new historicism technique Ahmed is certainly affected by her academic training in history as she follows the a similar methodology in her scholarly works like her Women and Gender in Islam: Historical Roots of Modern Debate 1992. Ahmed's reopening of personal and communal histories is not only considered a documentation of Muslim women history but also documentation and observation of its autonomy and its quality of border crossing. She does not only crosses time limitation by recounting history but also crosses the national borders as she demonstrated how the histories of different parts of the world are entangled and enmeshed though thought to be separated.

\section{Amina Wadud: An Example of Woman's Struggle for Equity}

Amina Wadud is an African-American convert to Islam who declared lately that she coincidently found out that her fore parents are of Moorish-Muslim background (Wadud "American by Force" 2011). She is a feminist scholar and university professor who has a noticeable impact on the debate about Islam and women through a hermeneutical approach as a solution to the women challenge in Islam. Her scholarly approach is governed by her dual position as both a woman and being from an African descent which entails an outlook to the women issues from a multiple prospective like that of hooks and Audre Lorde (Tuppurianen 249).

As a person who experienced racial exclusion before and after her conversion to Islam her answer to the women questions in Islam focuses on finding and highlighting the concept of equity as a foundational Islamic concept in the 
Quran. After she had embraced Islam during her college years she put this choice pending her research. She made a promise to herself to reread the scripture herself and vowing not to be a Muslim if she finds any reference to women inferiority (Hammer 446). Wadud was the pioneer to articulating the Qur'anic ethos of God-human and Human-human relations, for her it is through the Quran that we can identify the best meaning of equity (Al (Sahrmani 87). She introduces her 1999 Qur'an and Woman assuring the concept of gender equity in Islam as being based on the fullest meaning of mercy: "Mercifully, the more research I did into the Quran, .... The more affirmed I was that in Islam a female person was intended to be primordially, cosmologically, eschatologically, spiritually and morally a full human being" (ix-x). Wadud is probably the best-known American Muslim woman to have engaged in a gender-inclusive reinterpretation of the Quran (Hammer 444). She adopts a hermeneutical approach to the Quran that re-examines the text from a gender sensitive point of view to validate the women voice. Her widely known " Wadudian hermeneutics" considers not only the motives of the text as the typical practice in reading of religious scriptures but that of the reader as well (Jardim 9).

Wadud's Inside Gender Jihad 2008 retells her personal and academic story while reflecting on issues of women in Islam. She incorporates her background in linguistics and in religious studies in rereading women's position in the Quran as the Islamic holy book and on Muslim women history. Like Ahmed, Wadud's memoir is far from being a historical account; it is rather a critical reading of personal and communal history. Its structure differs from Ahmed's stream of consciousness technique, as she thematically arranges her narrative and builds each chapter on a certain issue within the Muslim women debate. Wadud who has extensive training in Arabic language and who spent a considerably long time of her academic life teaching at institutions in the Middle East extensively uses italicized Arabic language and Islamic terminology in her writings (Hammer 452). She systematically includes formal Arabic phonetically transcribed words to describe and define certain terms as oppose to the Egyptian colloquial used by Ahmed in her memoir. Wadud's title summarizes her life story and motivation to write it. It demonstrates her struggle for justice and equity both on the gender and race levels. The subtitle "Women Reform Islam" presents her usage of autonomous agency and commitment to change. It also sets the tone of the narrative and the author's purpose which is to "reform." Her purpose as explained by Khaled Abou El Fadl introducing her book is to show how surrender to God, which is the core meaning of Islam, entails an unwavering commitment to justice, integrity, truthfulness, and resistance to all forms of dominance and oppression. The meaningful surrender is thus a relentless Jihad xiagainst human weaknesses (x). Jihad or "to strive" for justices does not only highlight Wadud's life and scholarship, but it was also described by her as a "survival necessity" (Inside 254).

Wadud, who describes herself as being from a strong spiritual background, inherited her deep faith in divine justice from her father who was a Methodist minister, "a man of faith who lived and died poor, black man and had suffered from the racial discrimination of the American Society" (Inside 4). After converting to Islam, Wadud deconstructed her personal history from an Islamic prospective as she rethought her life "In reading the Quran, I relived my childhood sense of worlds of meaning through words" (ibid 9). She emphasizes that the central aim of the Quran is to "establish a viable social order on earth that will be just ethically based" (Inside 14), and thus dedicated her life and academic struggle to reestablish this social order based on justice and equity. Wadud opens her first chapter stating that her fascination with words and meaning that started early in her childhood and affected her lifelong journey to find meanings and broader definitions of words and concepts. Such admiration that affected her career as a linguist and hermeneutic analyst and is also demonstrated in the approach she uses in telling her story (Inside 14) ${ }^{\mathrm{xii}}$. The narrative is not chronologically arranged, each chapter discusses certain concepts and provides definitions to these concepts. Then the discussion is linked to her personal life as she gives examples from her own narrative. Wadud emphasized: "This book will include selective references to some of the experiences integral to my journey and theoretical conclusions" (Inside 24). Unlike Ahmad's literary technique, Wadud's method is influenced by her other academic works. It interweaves her scholarly research findings and analysis with her personal life and is entirely based on her linguistic and hermeneutic approach. Except for few poetry quotations, Wadud uses to emphasize some concepts ${ }^{x i i}$, she remained faithful to her academic approach in reading personal and communal history.

Wadud's shifting paradigm and autonomous initiatives challenge the sustained social and gendered order presumably suggested and maintained by Islamic history. She challenges the established order created by the one-dimensional reading of the Quran and inspires women of their divine right to full human dignity despite societal experiences of dismay and humiliation. Wadud embraced Islam fully convinced with its equality, justice and inclusion, however, social practices both at home and in countries like Libya, where she lived to work for few years, led her to pursue a moral struggle against women marginalization in the historical development of Islamic intellectual legacy (Inside 3). She also makes reference to other Muslim women writers and historians in their analysis of the position of women in Islam; she made more than one reference to Leila Ahmed and Fatima Mernissi for instance (Inside 20). She was mainly influenced by Ahmed in her historical approach and her usage of intersecting analysis of Orientalism and gender (Imtoual 443).

Justice as a main Qur'anic concept occupies a central position in Wadud's narrative. She critically comments on the gap between the intended meanings of the Quran as a text as it can be understood through its specialized reading and the common reading that has been historically reinforced. Her Tawhidic Paradigm ${ }^{x i v}$ Is a concept she articulated that rests on four central truths ${ }^{\mathrm{xv}}$. She uses the paradigm as an example to demonstrate the selective application of hierarchy and authority in Muslim communities. She recalls the Islamic study circles in local mosques and community gathering both at the US or in other Muslim countries she lived at and comments on the power hierarchy in these small communites ( Inside 25-40). Wadud draws some personal examples to demonstrate the divergence of the application of such Qur'anic concepts in the daily lives of Muslim women both in the past and in today's world. The examples from her life are used 
as evidence of the misinterpretation of the Qur'anic concepts and the repeated misapplication of Islam. The human being as Khalifa, a moral agent of Allah on Earth or "vicegerent" contradicts the humiliating and inferior position of women in Muslim societies (Inside 33-41).

One of the most controversial incidents in Wadud's life is her leading a Friday congregation prayers in 1994 at the Claremont Main Mosque in South Africa. Apart from the legislative debate that this incident raised all across the Muslim world, which is not the focus of the current study, Wadud narrates this event in the lights of the negotiations of power and leadership in Muslim communities (Inside 158-162). Wadud laments the universal silence about her speech despite its sincerity and importance as she addressed issues of central concern to Muslims. The debate raised by the event did not analytically discuss the content. It was rather focused on her gender and questioned the legality of her leadership of the prayer. She did not see gender as a religious requirement but rather is a result of customs of historical and cultural precedents (Calderini 330) ${ }^{\mathrm{xvi}}$. She reflects on the event in her memoir and comments on the words of her speech stating:

I submit them here to subject them and their context to rigorous analysis for social transformation in the arena of Islamic worship. These words flowed from the center of my innermost yearning as a woman in Islam. After they were brought forth in full voice in the public domain, the mark of their stature and significance has not been by their actual substance and particular voice (Inside 162).

Wadud sees the Cape Town episode as an opportunity to deconstruct gender hegemony which pushes for transformation and opens the doors for more investigation of women in Muslim societies (Inside 186). Thus the personal narrative is used here as an instigator of change and an autonomous act of reformation especially that she was later invited numerous times for congregational speech as detailed in the memoir (ibid 246, 249).

Wadud's religious/racial/gender struggle within Western academia is a life-long inner struggle. Though she initially embraced Islam believing that it will be her survivor from race and gender discrimination, she found herself in a new struggle as a Muslim woman especially in Western academia both as a student and later as an educator in religious studies department in the US (Inside 62-3). After many discriminative incidents in her academic life and particularly after 9/11 she gathered using Malcolm X's metaphor, "a Muslim woman academic is not an equal diner at the dinner table of academic life" (ibid 67). She also realized an increasing animosity from students that was clearly stated in some students' reviews especially because of her attire as she chose to wear hijab for more than 30 years. Nevertheless, Wadud took autonomous strides to change the discriminative situation in the academia. She participated in gender and religion conferences to create panels of Muslim women from different Muslim countries to show their initiatives of reconstructing Muslim women history both nationally and internationally. She also formed different study circles and proposes conference panels to the American Academy of Religion as a step further to establish the sub division of Muslim women studies(Inside 65-70). The triple fold struggle Wadud faced in the academic life is the triangle that shapes her identity as a poor African American Muslim woman. Thus her efforts in increasing the awareness of the disadvantageous situations of herself and women like her have was inspired and built on the need for the articulation and the philosophical development of non- white Western feminism (ibid 79).

Like all other Muslims living in the West and particularly women who wear hijab, the aftermath of 9/11 affected Wadud's self- realization and enforced a defensive position upon her as a person and as a professor of Islamic studies. The dehumanization of Muslims was massive as described by Wadud quoting a local Imam as a state of "erasure" of the humanity of Muslims in the American society (Inside 225). Especially women in hijab as they are the most identifiable they were the most vulnerable and subject to random acts of retaliation (ibid 228). To reconnect with Muslims and people of other religions was Wadud's response to the adversity of her situation was to reclaim her self- confidence and identity "To start reclaiming my wholeness I also needed to reaffirm this symbol (hijab) in my own Islamic right of choice. I moved out of the erasure by selecting to attend spiritual ceremonies, and inter-faith based activities focused on healing the whole of humanity" (Inside 227). Wadud notices that African- Americans despite being the largest Muslim group in America, their voices were not heard in response to the accusations against Islam, women, in particular, were entirely muted which she regards as an act of erasure both internally and externally (ibid 228). Wadud's response to these acts of erasure was more connectedness with women groups and more involvement in public events both nationally and internationally to enhance the Muslim women's voice in the public arena and find conflict resolution to the challenges of the new millennium (Inside 230).

Wadud addresses the issue of ethnocentrism as one of the main issues that has to be the subject of debate in political and women studies scholarships, she views this intersection of race and gender as a crucial problem in the North American society which directly affect Muslim communities outside the US as well. Her choice of gender Jihad was her proposed solution both on the personal and professional scholarly levels. Her academic and public addresses which she included in a separate chapter in her memoir, promotes for her looking forward approach. The outlook entails

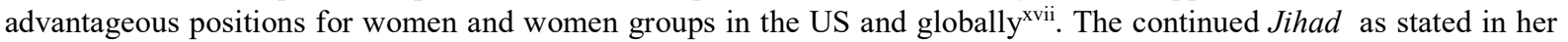
concluding chapter titled "Why Fight the Gender Jihad" is to continue to "tell a part of the grand story", the story of the dehumanization of the female identity (Inside 255). Wadud fought the gender Jihad both on the personal, academic and public levels to "remove the blinders that see only the illusion of fragmentation and then build structures and formulate systems to sustain the perception that it is real" ( ibid 257). Wadud's aspiration for a future Islamic dispensation in which women are fully emancipated is expressed in her slogan "I dream of Islam without patriarchy"(1999, 91). Wadud's hermeneutics exceeds the limitations of the past, for she does not only call for a rereading of the Quran in order to re define the women's voice. Furthermore, she looks forward to creating women 
progressive groups that implement and enhances women voice in Muslim societies. Her Look Forward initiative through which she calls for overriding the racial grouping amongst woman activists by representing power within women groups, not over them (Tuppurianen 2010, 251). Therefore the focus of her ongoing work has been the rehabilitation of the Qur'anic interpretation of women and men from a pluralist inclusive prospective (Smith 2011, 194).

\section{Conclusion}

In conclusion the current study demonstrates the ability of both writers to reposition themselves within the cultural poetics of their communities as they utilized personal and academic narratives to instigate autonomous social promotion. As per the main objectives of this study, it specifically revealed the authors' approaches to revisit personal and communal histories of women in Muslim societies and to recreate a current and future clearer image of Muslim women both at home and in the diaspora. The study is significantly different from previous investigations in the field as it concurrently examines the personal and the communal histories of both writers. Additionally the study explored the uniqueness of the autobiography as a literary text to incorporate historical and linguistic dialogues into the personal narratives $^{\text {xviii. }}$ Leila Ahmed's A Border Passage and Amina Wadud's Inside the Gender Jihad provide a clear example of the personal, communal testimonial writings. Both writers reconstructed their personal lives as examples of the development of women status in their societies. Though both live and work in the United States, they create critical connections with Muslim women history in Muslim countries particularly with Egypt and the Middle East in the case of Ahmed and with other Muslim countries as well like Indonesia in the case of Wadud. Their revision of their cultural poetics included incorporation of personal life as Muslim women themselves, with academic and professional analysis as specialists in the field of women studies. As both scholars experienced different hurdles in their personal and scholarly path, their memoirs embody the theme of crossing and overcoming. Both memoirs are written from the new historicism perspective which entails incorporating historical events within the main literary text. Both Leila Ahmed and Amina Wadud incorporate personal and communal narratives to reposition women in Islamic history. Though following different approaches, both provide a paradigm shift in the history of women in Islam, both used their personal narratives as the corpus for academic analysis of issues concerning discrimination, justice and gender equality. Though autobiography in general is thought to be an art of "writing back" (Golley 15), the reflections and analysis both writers included along with their personal narratives evidently showed the further dimensions intended than the mere act of narration. Additionally, the study clearly demonstrated the different approaches the two writers followed to activate Muslim women autonomy. While Ahmed's approach is described by Tuppurianen as a looking back approach that depends on reflecting on one's own history and achievements $(224,228)$, the current reading as evident in this study provided evidence that Ahmed's approach used history as a point of departure to instigate Muslim women autonomy and action. Additionally, the study provided examples of Wadud's usage of hermeneutics to pave the way for Muslim women collective actions and autonomy. An approach that is described by Tuppurianen as looking forward (249) which depends mostly on the rereading of the Quranic text. The finding of this study demonstrated how Wadud utilized her personal narrative to reflect on her academic writings and to connect between the two to inspire Muslim women advancement.

Despite their different approaches to redefining women in Islam and the apparent contradiction in their methodologies, education represents a concurrent theme and common ground in both Ahmed's and Wadud's works. They both see women education as an empowering agent that will enable women to regain their status in Islam as granted by Islam's premier source the Quran. Education was a liberating factor in Ahmed's life, it enabled her to redefine and reposition herself as a prominent figure in the field of women studies. She examined the development of liberating movements and enlightenment in the Middle East especially since the early nineteenth century and provided evidence of the impact of education in the recreation of women's identity in the region (Gender 1992 189-209). Likewise, Wadud regards education and re-education of both Muslim men and women within Islamic history and faith as the main liberator of women from the historic/cultural shackles of single-mindedness and stagnant positions for women (Inside 262 \& Quran and Women 1-15).

In the two texts, history is the protagonist that foregrounds the personal narratives. Both texts are rich with reflections on historic events and present a Muslim women outlook to overcome the triple discriminative positions (racial, gender and political) in social and academic institutions. Both texts present an image of Muslim women activism and independence that deviates substantially from the dominant stereotype of the liberal savior represented by Western White feminism. The two works can also provide documentation of the battle against marginalization and devaluation of non-white feminism in the field of women studies in America. As academic professionals, both writers document such battle within the theme of a crossing. Both texts are complemented with the other scholarly works and presentations of their authors in the field of women studies. They reflect on the field of women studies and propose measures for development through inclusion, diversity, and panels in conferences and seminars. Both narratives suggest liberation from the dual controlling cultural patterns of the Muslim past and the present patronizing dominant culture of white feminism. Hence they both propose Muslim women autonomy within deconstructing Islamic history and restructuring of power in Islamic societies both at home and in the diaspora. Both texts are rich mines of information and analysis and deserve additional critical analysis in the future. As suggested by both writers in their narratives and in other scholarly works as well, Muslim women autonomy and advancement can only happen within the Islamic context as a signifier. Undoubtedly, these two scholars have evidently helped in making the Muslim women voice more audible in the academic and public spheres in the American society. 


\section{References}

Abou El Fadl, Khaled, Foreword, Inside the Gender Jihad: Women's Reform in Islam, One World Publishing, USA, 2008, vii-xvii.

Aboul-Ela, Hosam, Edward Said's "Out of Place": Criticism, Polemic, and Arab-American Identity, MELUS, Vol. 31, No. 4, Arab American Literature (Winter, 2006), 5-32.

Afzal-Khan, Fawzia ed. Shattering the Stereotypes: Muslim Women Speak Out, Olive Branch Press, US, 2005.

Ahmed, Leila, A Border Passage: From Cairo to America- a Woman's Journey. New York: Penguin (1999, 2012).

---- Women \& Gender in Islam, Yale University Press, New Haven \& London, 1992. ProQuest ebrary. Web. 26 February 2016

---- "Early Islam and the position of women: The problem of interpretation." Keddie, N. and Baron, B. (Eds), 1991. ProQuest ebrary. Web. 26 February 2016 Retrieved from http://www.jstor.org/stable/3174138

---- "Women and the Advent of Islam". Signs 11.4, 1986, 665-691.

Anderson, L. R. Women and Autobiography in the Twentieth Century: Remembered futures. Prentice Hall, USA, 1997.

Badran, Margot, Feminists, Islam and Nation: Gender and the Making of Modern Egypt; Princeton University Press, New Jersey,1995.

Barbour, J. D., "The Consolations and Compensations of Exile: Memoirs by Said, Ahmed, and Eire. Journal Of The American Academy Of Religion,79(3), 706-734, 2011.

Barlas, Asma; Believing Women in Islam, Understanding Patriarchal Interpretations of the Qur'an, University of Texas Press, Austin (seventh reprinting) 2011.

-------, "The Qur'an, Sexual Equality, and Feminism" University of Toronto, January 12, 2004. Online: ttp://www.asmabarlas.com/TALKS/20040112_UToronto.pdf date of access: 1-13-2013.

Bhavnani, Kum-Kum, \& Meg Coulson, "Race," A Concise Companion to Feminist Theory, Mary Eagleton ed. Blackwell Publishing: MA, 2003

-------"The Influence of Social Movements on Articulations of Race and Gender in Black Women's Autobiographies," Gender and Society, 1999, 120-37.

Calderini, S. "Islam and Diversity: Alternative Voices within Contemporary Islam”. New Blackfriars, 89(1021), 324336. 2008. Web. 13 February 2016 Retrieved from 10.1111/j.1741-2005.2008.00224.X

Collins, Patricia Hill. Black Feminist Thought: Knowledge, Consciousness, and the Politics of Empowerment. New York, Routledge, 1991.

Davis, R. G. Academic autobiography as women's history: Jill Ker Conway's True North and Leila Ahmed's A Border Passage. Rethinking History, 13(1), 109-123. 2009. Web. 13 February 2016 Retrieved from ProQuest ebrary. http://www.jstor.org/stable/317413810.1080/1364252080263970

Doorn- Harder, Pieternella, Women Shaping Islam; Reading the Qur'an in Indonesia; University of Illinois Press, Urbana, and Chicago, 2006.

Duderija, Adis; " Review of A. Barlas: Believing Women in Islam- Unreading Patriarchal Interpretations of the Qur'an", Middle East Studies Online Journal, Volume 1 No2. 2010, http://www.jstor.org/stable/3174138Date of access 1-132013.

Fernea, Warnock; In Search of Islamic Feminism, One Woman's Global Journey Anchor Books, and New York: 1998.

Fieldman, Keith. "Poetic Geographies: Interracial Insurgency in Arab American Autobiographical Spaces," Arab Woman's Lives Retold: Exploring Identity Through Writing. Nawar Al Hasan Golley (ed.), Syracuse University Press, NY, 2007.

Golley, Nawar Al Hasan, Reading Arab Women's Autobiographies, University of Texas Press, Austin 2006.

Greenblatt, Stephen, Renaissance Self-Fashioning: From More to Shakespeare. Chicago: University of Chicago Press. 1980- 2005.

Hammer, Juliane. "Identity, Authority, and Activism: American Muslim Women Approach to Quran," the Muslim World, Oct. 2008, 443-64.

Hassan, Wail, and Arab- "American autobiography and the reinvention of identity: Two Egyptian Negotiations." Alif: Journal of Comparative Poetics 22: 7-38, 2002.

Imtoual, Alia "A View From Feminist Muslim Scholarship," Australian Feminist Studies, vol. 25, No. 66, December 2010 .

Jordan, June. Some of Us Did Not Die, New York: Basic Civitas Books, 2002.

Karmarae and Treichler, A Feminist Dictionary, Pandora Press, 1985,http://www.jstor.org/stable/464171

Jardim, Georgina L, Dr. Recovering the Female Voice in Islamic Scripture. Farnham, GB: Ashgate, 2014. ProQuest ebrary. Web. 26 February 2016. 


Al Khadrawy, Deeb. Dictionary of Islamic Terms, Al Yamama Publication, Damascus, 2004.
http://www.waqfeya.com/book.php?bid=6538

Lorde, Audre Sister Outsider; Essays\& Speeches by Audre Lorde. New York: Crossing Press. 1984, 2007.

Mernissi, Fatima, Women's Rebellion and Islamic Memory, London: Zed, 1996.

Montrose, Louis "Professing the Renaissance: The Poetics and Politics of Culture" in Literary Theory: An Anthology, Blackwell Publishing, MA, 2006.

Myers, D. G. "New Historicism in Literary Studies," Academic Questions, March, Volume 2, Issue 1, 27-36, 1989.

Nash, Geoffrey. "From Harem to Harvard; Cross-Cultural Memoir in Leila Ahmed's A Border Passage" In Arab Voices in Diaspora: Critical Perspectives on Anglophone Arab Literature. Rodopi, Amsterdam, 351-370, 2009.

Rivkin, Julie and Michael Ryan (ed.) "Introduction: Writing the Past" in Literary Theory: An Anthology, Blackwell Publishing, MA, 2006.

Said, Edward. Orientalism. New York: Pantheon Books, 1978.

Sharawi, Huda. Harem Years: The Memories of an Egyptian Feminist. Trans. Margot Badran. Virago, London 1986.

Al-Sharmani, Mulki. "Islamic Feminism, Transnational and National Reflections," Approaching Religion, vol. 4. No. 2, 83-94, 2014.

Smith, Barbra. "Toward a Black Feminist Criticism," All the Women Are White, All the Blacks Are Men, but Some of Us Are Brave, Old Westbury, NY, Feminist Press, 1982.

Smith, Jane. “American Muslims and Religious Pluralism”1. Religion Compass, 5(5), 192-201. 2011. doi:10.1111/j.1749-8171.2011.00270.x

Sundquist, Eric. "Melville, Delany, and New World Slaver," in Rivkin, Julie and Michael Ryan (ed.) Literary Theory: An Anthology, Blackwell Publishing, MA, 2006. 621-40.

Tuppurianen, Anne Johanna." Challenges Faced by Muslim Women: an Evaluation of the Writings of Leila Ahmed, Elizabeth Fernea, Fatima Mernissi and Amina Wadud", Ph.D. Thesis, University of South Africa, May 2010 http://uir.unisa.ac.za/bitstream/handle/10500/3951/thesis_tuppurainen_a.pdf.txt?sequence=3 date of access 31/1/2013.

Wadud, Amina. Qur'an and Woman, Re-reading the Sacred Text from a Woman's Perspective, Oxford University press, New York: 1999.

-------,"Qur'an, Gender and the Interpretive Possibilities," HAWA2, 3, Koninklijke Brill, NY, Leiden, 2004.

-------, Inside the Gender Jihad: Women's Reform in Islam, One World Publishing, USA, 2008.

-------, American by Force, Muslim By Choice." Political Theology 12.5 (2011): 699-705. Academic Search Complete. Web. 18 Nov. 2016.

Whitlock, Gillian. Postcolonial Life Narrative, Testimonial Transactions, Oxford University Press, 2015.

Vinson, Pauline Homsi. "Shaharazadian Gestures in Arab Women's Autobiographies: Political History, Personal Memory, and Oral Matrilineal Narratives in the Works of Nawal El Saadawi and Leila Ahmed," NWSA Journal, Vo. 20, no. 1 (spring). 78- 982008.

Yaqin, Amina. “Autobiography and Muslim Women's Lives” Journal of Women's History, Vol. 25. No.2. 171-184, 2013.

\section{Notes}

i The term "New Historicism" refers to the use of history in the literary analysis which is not "new" however the application of using multiple factors in the study differs from the traditional historical analysis. The term was later questioned by many critics and even by Stephen Greenblatt, its founder during the 1980s, and he suggests the use of Cultural Poetics to describe his practice. See Julie Rivkin \& Michael Ryan chapter "Introduction: Writing the past" in Literary Theory an Anthology, 2006.

ii Feminism as a discourse is tough to define, Karmarae and Treichler define it in A Feminist Dictionary as:" a conscious stand in opposition to male defamation and mistreatment of women; and a belief that the sexes are culturally, and not just biologically, formed"(158). It is as a political discourse aims at equal rights and legal protection for women, it involves various movements, theories, and philosophies, the objective of this research is not to examine feminism in itself however it is using feminist approach to the understanding of women status in Islamic societies. It is not limited to one definition of feminism in Western ideology.

iii. In her survey of current activism of Islamic feminism Mulki Al- Sharmani included many definitions such as that of the well-known anthropologist and one of the pioneers of Islamic feminist Ziba Mir-Hosseini who defines it as "new consciousness, new way of thinking, a gender discourse that was feminist in the aspiration and demands, yet Islamic in its language and source of legitimacy" (2006 640).

iv See Amina Yaqin's “Autobiography and Muslim Women's Lives” 2013, for more examples of Muslim women autobiographies. 
v For more understanding about their academic approaches to Muslim women autonomy see Ahmed's Women \& Gender in Islam, Yale University Press, New Haven \& London 1992 and Wadud's Qur'an and Woman, Re-reading the Sacred Text from a Woman's Perspective, Oxford University Press, New York: 1999.

vi. Leila Ahmed is an internationally acclaimed Muslim women scholar whose work and analytical approach to women history in Islam can never be undermined or underestimated, however, for the particular objective of this study and the space limitation of this research only her personal memoir is to be examined in details.

vii Wadud's Looking forward will be discussed in more details below.

viii Besides the example of Leila Ahmed, see in Davis' the example Jill Ker Conway as an academics who combines her personal biography with her reflections on academic experience in higher education as a woman advocate and pioneer in academic leadership $(2009,109)$.

ix Sharawi's Harem Days was dictated to Huda's secretary in Arabic and he wrote it in English which makes it a unique document about women in Egypt in English and was rewritten by Margot Badran in English on 1986 (Al- Hasan Gholley 2003, 35).

x The "gyp" is the name given to women cleaners and helpers at Girton, it is defined at the Oxford Dictionary as a derivative from the word past, varlet or from gypsy which is a "wandering race ..... believed to have come from Egypt". She finds the name "gyp" enough discriminative and was somehow surprised to see it acceptable and commonly used in Western academia that was supposedly opposing oppressive and discriminative descriptions (Ahmed 2012, 179).

${ }^{x i}$ Despite the correct Arabic meaning of the word Jihad which literally means to struggle or to strive; I believe it is not culturally or politically appropriate to use especially after $9 / 11$ as it developed negative connotation that may imply meanings were not intended by the author.

xii All Arabic Islamic terms are written in Italics in Wadud's Jihad and are explained in English in the book.

xiii See Wadud's references to Shakespeare p. 14 and Mohaja Kahf p. 121 for instance.

xiv The word Tawhid in Arabic means believing in the oneness of Allah which indicates the ultimate believe and surrender to His doctrine and concepts clearly stated in the Quran. Equity is one of these Quranic concepts.

xv The four bases are: 1- God is one, 2- human beings are in vertical relationships with God in which they seek to know and worship him in their capacity as God's vice-regents on earth. 3- Human beings can only be in the horizontal relationship with one another and 4- the Quran as the word of God has a hierarchy of meanings that that point to the trajectory of justice ( see Inside (24- 40).

${ }^{x v i}$. It is not the intention of this study to indulge into the religious discussions aroused by this event or any other incidents in both books as it is not within the scope of this research as my purpose here remains the literary analysis of the texts as life testimonials.

xvii My primary concern here is to demonstrate Wadud's struggle not to analyze her personal/religious ideas though her addresses are rich sources for debates on ethnocentric issues that may interest many researchers in these fields.

xviii See Tuppurianen 2010, Geoffrey 2009, Davis 2009, Hassan 2002, and others. 